\title{
«ПРЕСТУПЛЕНИЯ НЕНАВИСТИ» В УГОЛОВНОМ ЗАКОНОДАТЕЛЬСТВЕ ГОСУДАРСТВ СЕМЬИ ОБЩЕГО ПРАВА (ВЕЛИКОБРИТАНИЯ, США, КАНАДА, АВСТРАЛИЯ, НОВАЯ ЗЕЛАНДИЯ)
}

Аннотация: Предложен анализ уголовного законодательства о "преступлениях ненависти" государств, входящих в семью общего (англосаксонского) права: Соединенного Королевства, Соединенных Штатов Америки, Канады, Австралии и Новой зеландии. Названы признаки, по которым в правовых системах этих государств квалифицируются «преступления ненависти»: раса, ивет кожи, национальность (включая гражданство), этническое происхождение, религия, гендерная идентичность, сексуальная ориентация, возраст, недееспособность (нетрудоспособность) и др. Особое внимание в законодательстве названных государств уделяется установлению умысла ("намерения») виновного и чувства страха, беспокойства или унижения, испытываемого потерпевшим (потерпевшими) в связи с совершенным против него (них) посягательством. Описаны отдельные меры, предпринимаемые законодательными и исполнительными органами вышеперечисленных государств по устранению пробелов и, в конечном счете, расширению сферы применения норм об уголовной ответственности за их совершение. Делается вывод в целом о достаточно строгом характере наказаний, назначаемых за их совершение.

Ключевые слова: уголовное законодательство Великобритании, уголовное законодательство США, преступления, мотивированные ксенофобией, расовая дискриминация, пропаганда ненависти, разжигание ненависти, преступления ненависти, уголовное законодательство Канады, уголовное законодательство Австралии, уголовное законодательство Зеландии.

DOI: 10.7256/1994-1471.2014.5.10156

B еликобритания. В стране действует несколько статутов, которые предусматривают уголовную ответственность за «преступления ненависти»: об общественном порядке (1986 г.); о расовой и религиозной ненависти (2006 г.); об уголовной юстиции и иммиграции (2008 г.). Эти законы запрещают разжигание ненависти из-за цвета кожи, расы, национальности (включая гражданство), этнического или национального происхождения, религии или сексуальной ориентации ${ }^{1}$. Для квалификации необходимо установление умысла («намерения») виновного вызвать расовую ненависть, а также «чувства беспокой-

Public Order Act 1986//<http://www.legislation. gov.uk/ukpga/1986/64/contents> (последнее посещение-28.10.2013); Racial and Religious Hatred act 2006 (England and Wales)// <> (последнее посещение-28.10.2013); Criminal Justice and Immigration Act 2008//<> (последнее посещение-28.10.2013). ства, страха и унижения», возникшие в связи с этим у потерпевшего. Оскорбления и угрозы (не только словом или поведением, но и письменными материалами и изображениями) по вышеперечисленным признакам наказываются штрафом или тюремным заключением (до 7 лет) либо и тем, и другим.

С 1998 г. действует Закон «0 преступлении и беспорядках» (Часть вторая «Уголовное право», статьи 28-32), который устанавливает уголовную ответственность не только за совершение преступления на почве («полностью или частично») вражды по отношению к членам расовой или религиозной группы, но и за демонстрацию непосредственно до совершения преступления или после него враждебности по отношению к жертве преступления в связи с действительной или предполагаемой принадлежностью жертвы к расовой или религиозной группе. В этом же законе раскрываются понятия «расовая группа» и «религиозная группа».

(C) Велиев Фахри Закир оглы

Аспирант кафедры уголовного права, Московский государственный юридический университет имени О. Е. Кутафина (МГЮА)

[vfzo@mail.ru]

127474, Россия, г. Москва, Бескудниковский бульвар, д. 19, корп.1. 
Расовая группа - это группа лиц, «определяемая по признаку расы, цвета кожи, национальности (включая гражданство) либо этнического или национального происхождения». В свою очередь, религиозная группа означает группу лиц, определяемую не только по наличию религиозных убеждений, но и, что важно, «отсутствию религиозных убеждений» ${ }^{2}$.

В упомянутом Законе установлена также самостоятельная ответственность за преступления, совершаемые по рассматриваемым мотивам. Так, уничтожение или повреждение чужого имущества по расовым или религиозным мотивам наказывается в порядке суммарного производства к лишению свободы на срок до 14 лет. Домогательство, вынуждающее людей жить в страхе применения к ним насилия, совершенное по этим же мотивам, наказывается максимально лишением свободы на срок до 7 лет ${ }^{3}$.

В стране предусмотрена ответственность также за «неприличное или расистское пение» во время футбольных матчей (Закон о футболе (преступлениях и нарушениях) 1991 г.) ${ }^{4}$.

Английские законы содержат особо суровые санкции за умышленные посягательства против жизни, мотивированные ксенофобией. Так, согласно Закону об уголовном правосудии (2003 г.), для лица, совершившего в возрасте 21 года тяжкое убийство, в частности, «с целью способствовать религиозным соображениям», минимальным наказанием является пожизненное лишение свободы. Для лица же, совершившего тяжкое убийство в возрасте старше 18 лет, минимальный срок лишения свободы составляет 30 лет, если данное преступление отягчено «расовыми или религиозными соображениями» ${ }^{5}$. Кроме того, данный Закон в целом «совершение преступления по расовым или религиозным мотивам» рассматривает как отягчающее обстоятельство при назначении наказания 6 .

Соединенные штаты Америки. Первым актом в США против преступлений на расовой почве был Закон о гражданских правах 1871 г. (Civil Rights Acts of 1871). На сегодняшний день

\footnotetext{
Crime and Disorder Act $1998<$ http://www.legislation. gov.uk/ukpga/1998/37/section/28> (последнее посещение-17.07.2013).

См. также: Кочои С. М. Расизм: уголовно-правовое противодействие. М.: Проспект, 2007. С. 16-21.

http://www.legislation.gov.uk/ukpga/1999/21/notes/ contents(последнее посещение-28. 10. 2013).

Есаков Г. А., Крылова Н. Е., Серебренникова А. В. Уголовное право зарубежных стран: учебное пособие. М.: Проспект, 2013. С. 268-269.

6 Есаков Г. А., Крылова Н. Е., Серебренникова А. В. Указ. раб.С. 276.
}

официальных определений «преступлений ненависти» в уголовном законодательстве США несколько. Так, Закон о гражданских правах 1968 г. ((Раздел 18 Свода Законов США, §245(b) (2)) предусматривает федеральное уголовное преследование любого, кто «умышленно оскорбляет, угрожает или вредит другому, либо пытается это сделать с помощью силы, по признаку расы, цвета кожи, религии или национальной принадлежности»7. За нарушение указанного Закона может быть назначен штраф или тюремное заключение сроком до одного года. Однако если указанные в Законе действия связаны с использованием огнестрельного оружия, взрывчатых веществ или поджога, то срок тюремного заключения может быть равен 10 годам. Если же указанные преступления связанны с похищением людей, сексуальным насилием или убийством, то они могут быть наказаны пожизненным тюремным заключением или смертной казнью.

Надо сказать, что действие данного закона носит ограниченный характер, и он применялся лишь в связи с участием потерпевшего в конкретной деятельности, в частности, учебой в государственных школах, деятельностью в качестве присяжного, участием в других сферах федеральной государственной деятельности (федеральные выборы, трудоустройство в федеральное учреждение и др.). Однако реформа 2009 г. (см. ниже) отменила эти ограничения и расширила условия, при наличии которых преступление может преследоваться как «преступление ненависти».

Согласно Закону о статистике преступлений ненависти 1990 г. (Public Law 101-275), «преступлениями ненависти» признаются «преступления, которые свидетельствуют о наличии предрассудков по признаку расы, религии, сексуальной ориентации или этнической принадлежности, включая в соответствующих случаях такие преступления, как убийство, простое умышленное убийство, изнасилование, нападение при отягчающих обстоятельствах, простое нападение, угроза, поджог, уничтожение, повреждение или нанесение ущерба собственности». Стоит отметить, что данный Закон, подписанный Дж. Бушем-младшим, был первым законом, призванным защищать геев, лесбиянок и бисексуалов.

Федеральный закон 1994 г. «0 контроле и предупреждении преступлений» (Public Law 103-322A) определяет «преступление ненависти» как преступление, в котором преступник «намеренно выбирает жертву ... в связи

http://www.law.cornell.edu/uscode/text/18/245 (последнее посещение-28.10.2013). 
с фактической или предполагаемой расой, цвета кожи, религии, национального происхождения, этнической принадлежности, пола, недееспособности или сексуальной ориентации человека» ${ }^{8}$. Данный закон впервые среди признаков, по которым совершается «преступление ненависти», назвал недееспособность (нетрудоспособность).

Необходимо заметить, что свое определение «преступлений ненависти» предлагает и Федеральное Бюро Расследований. На официальном сайте этого ведомства «преступление ненависти» определяется как уголовное посягательство, совершенное против личности, собственности или общества, «которое мотивировано, полностью или частично, предубеждением правонарушителя против расы, религии, недееспособности, сексуальной ориентации или этнического (национального) происхождения» ${ }^{9}$.

28 октября 2009 г. Президент Барак Обама подписал Закон «О предупреждении преступлений ненависти», подготовленный Мэтью Шепардом (Matthew Shepard) и Джеймсом Бердом-младшим (James Byrd. Jr.). Если Закон о гражданских правах 1968 г. преступлением ненависти считал посягательство только по признакам расы, цвета кожи, религии, этнической или национальной ненависти, то Федеральный закон 2009 г. к вышеперечисленным признакам добавил действительную или предполагаемую сексуальную ориентацию, гендерную идентичность, пол и инвалидность. Кроме того, Закон отменил такое условие привлечения к ответственности, как совершение рассматриваемого преступления в одной из сфер федеральной государственной деятельности.

В настоящее время 45 штатов и округ Колумбия имеют статуты о преступлениях ненависти, защищающие различные группы населения $^{10}$. Во всех из этих штатов наказуемы посягательства по признакам расы, религии и этнической принадлежности. Дополнительно под охрану поставлены:

- недееспособность - в 32 штатах;

- $\quad$ сексуальная ориентация - в 31 штате;

- $\quad$ пол - в 28 штатах;

- гендерная идентичность - в 16 штатах;

- $\quad$ возраст - в 13 штатах;

- политическая принадлежность - в 5 штатах;

Questions and answers: what's wrong with thought Crime («Hate crime») Laws <> (последнее посещение-28.10.2013).

9 Hate Crime Definition//www.fbi.cov/ (последнее посещение-28.10.2013).

10 Первым такой статут в 1978 г. принял штат Калифорния. До сих пор подобных статутов не имеют штаты Арканзас, Джорджия, Индиана, Южная Каролина и Вайоминг.
- $\quad$ бездомность - в 3 штатах, а также в Вашингтоне и округе Колумбия.

Кроме этого, 31 штат и округ Колумбия, в дополнение к уголовной ответственности за «преступления ненависти», приняли статуты о гражданской ответственности, а 27 штатов и округ Колумбия имеют законы, обязывающие правоохранительные органы вести статистику «преступлений ненависти».

Ежегодно Министерство юстиции и ФБР публикуют статистику «преступлений ненависти». Согласно этим данным, начиная с 1991 года, из более чем 113000 преступлений на почве ненависти 55\% были мотивированы расовыми предрассудками, $17 \%$ - религиозными предубеждениями, 14\% - этнической предвзятостью. Кроме того, 14\% преступлений совершены по признаку сексуальной ориентации, 1\% - недееспособности ${ }^{11}$. В 2006 г., по статистике ФБР, среди «преступлений ненависти» против личности преобладали такие преступления, как угрозы, простые нападения, преступления против собственности (уничтожение, повреждение, вандализм). В 2007 г. к указанным преступлениям были перечислены 9 убийств и 2 изнасилования (из 17000 убийств и 90000 изнасилований, совершенных в 2007 году).

В ходе дебатов о законах за «преступления ненависти» председатель Верховного Суда США Уильям Ренкуист (William Rehnquist), выступая за ужесточение наказаний в случае их совершения, заявил, в частности, что они причиняют большой вред их жертвам, «в состоянии спровоцировать ответные преступления и подстрекают к беспорядкам в обществе» ${ }^{12}$.

Вместе с тем в американском обществе имеются специалисты, выступающие против выделения такой группы преступлений. По их мнению, это противоречит фундаментальным правам и свободам человека. Например, в своей книге «Преступления ненависти: уголовное право и политика идентичности» профессор юридического факультета Нью-Йоркского университета Джеймс Якобс (James B. Jacobs) и Кимберли Потер (Kimberly Potter) критикуют законодательство о преступлениях ненависти, так как оно, по их мнению, определяет

11 Abrams, J. House Passes Extended Hate Crimes Bill, Guardian Unlimited, 05-03-2007// <> (последнее посещение-28.10.2013).

12 Решение Верховного Суда США по делу Wisconsin v. Mitchell, 508 U.S. 476 (1993). В этом решении Верховный Суд единодушно признал, что установление наказания за «преступления ненависти» не противоречит свободе слова, а позволяет суду оценивать мотивы при вынесении приговора за поведение, которое противоречит Первой поправке к Конституции США. 
таковыми посягательство одной группы людей против другой, а не против всего общества, что чревато обострением конфликтов между этими группами и ростом преступности ${ }^{13}$. Они же выступили против призыва ряда известных политиков и писателей об исключении из категории «преступления ненависти» преступлений против «белых» (которые в разные годы составляли пятую часть жертв таких преступлений) на том основании, что они не относятся к «защищенным группам» («меньшинствам»). По мнению Дж. Якобса и К. Поттера, это может вызвать «социальные конфликты и конституционно-правовые проблемы».

Канада. «Преступлениям ненависти» посвящены соответствующие положения Уголовного кодекса, Закона о правах человека, других федеральных законов, законодательства всех десяти провинций ${ }^{14}$ и трех территорий. В частности, УК запрещает «пропаганду ненависти», а Закон о правах человека - дискриминацию по различным признакам и «размещение ненависти» в сети Интернет.

Статьи 318, 319 и 320 УК под пропагандой ненависти понимают любые письменные материалы, изображения и заявления, которые выступают в защиту геноцида или поддерживают геноцид ${ }^{15}$.

Статья 318 предусматривает лишение свободы на срок до 5 лет за геноцид, под которым понимается уничтожение «определенной группы». При этом УК определяет указанную группу как «любая часть населения, которая отличается цветом кожи, расой, религией, этническим происхождением или сексуальной ориентацией».

Статья 319 предусматривает наказания от штрафа до лишения свободы на срок не более 2 лет за подстрекательство к ненависти в отношении какой-либо «определенной группы».

Статья 320 предусматривает конфискацию публикаций, «пропагандирующих ненависть».

В 1996 г. Федеральное правительство внесло поправку в УК, согласно которому отягчающим обстоятельством признается совершение преступления по мотивам «предвзятости, предубеждения или ненависти по признакам расы, национального или этнического проис-

\footnotetext{
13 Jacobs, James B. \& Kimberly Potter. (1998). Hate Crimes: Criminal Law and Identity Politics. New York: Oxford University Press, pp. 130-144.

14 Впервые в Северной Америке (1947 г.) именно одна из канадских провинций - Саскачеван - приняла закон о запрете дискриминации (по признакам расы, религии, цвета кожи, пола, национальности, происхождения и места проживания).

15 http://laws-lois.justice.gc.ca/eng/acts/C-46/(последнее посещение-28.10.2013).
}

хождения, языка, цвета кожи, религии, пола, возраста, умственной или физической недееспособности, сексуальной ориентации или любых других аналогичных факторов» ${ }^{16}$.

Австралия. Федеральный закон о расовой дискриминации (1975 г.) запрещает разжигание ненависти, если это деяние «с разумной степенью вероятности, с учетом всех обстоятельств дела», обидит, оскорбит, унизит или запугает другого человека или группу людей из-за расы, цвета кожи, национального или этнического происхождения ${ }^{17}$. Данный Закон был применен, в частности, в деле Джоунс против Тобена (Jones v. Toben). Дело касалось жалобы на сайт, который содержал материал, отрицавший холокост. Федеральный суд постановил, что данный материал является нарушением закона ${ }^{18}$.

Законы о расовой дискриминации приняты и действуют также на территории австралийских штатов:

- Нового Южного Уэльса (Закон 1977 г.);

- Западной Австралии (поправки к УК штата 1989 г.) ${ }^{19}$;

- Квисленда (Закон 1991 г.);

- $\quad$ Южной Австралии (Закон 1996 г.);

- Тасмании (Закон 1998 г.);

- Виктории (Закон 2001 г.).

Кроме того, соответствующие законы приняты на Австралийской столичной территории (1991 г.) и Северных территориях (1992 г.).

Новая Зеландия. Разжигание ненависти запрещено Законом о правах человека (1993 г.), статья 63 которого объявляет незаконным публикацию или распространение «угрожающих, оскорбительных или обидных слов с вероятностью вызвать враждебное отношение или унижение любой группы лиц по признаку цвета кожи, расы, этнического или национального происхождения». Согласно ст. 131, наказуемо также подстрекательство к «расовой дисгармонии».

В 2002 г. правительство выступило с поправками в законодательство, которые придают значение отягчающего обстоятельства преступлениям, «связанным с враждебным отношением к группе лиц по признаку расы, цвета кожи, национальности, религии, гендерной

16 O'Grady, William (2011). Crime In Canadian Context: debates and controversies. Oxford University Press, p. 161.

17 http://scaletext.law.gov.au/html/comact/9/4573/0/ CM000080.htm (последнее посещение-28.10.2013).

18 https://opennet.net/research/regions/australia-andnew-zealand (последнее посещение-28.10.2013).

19 Интересно, что в Западной Австралии предметом анализируемого преступления законодательство рассматривает только письменные материалы или графическую информацию, а не словесные комментарии. 
идентичности, сексуальной ориентации, возраста или недееспособности» ${ }^{20}$.

Таким образом, уголовное законодательство государств семьи общего права характеризуется не только «традиционным набором» признаков, по которым посягательство квалифицируется как «преступление ненависти» (раса, этническое происхождение, религия, национальность, цвет кожи), но также иными признаками, которыми характеризуются те или иные группы людей (недееспособность, отсутствие жилья, сексуальная ориентация, гендерная идентичность и др.). При этом посягательства по указанным признакам наказываются достаточно строго от штрафа до смертной казни (или пожизненного тюремного заключения).

\section{Библиография}

1. Есаков Г. А., Крылова Н. Е., Серебренникова А. В. Уголовное право зарубежных стран: учебное пособие. - М.: Проспект, 2013. 334 с.

2. Кочои С. М. Расизм: уголовно-правовое противодействие: монография. - М.: Проспект. 2007. $144 \mathrm{c}$.

3. Abrams, J. House Passes Extended Hate Crimes Bill, Guardian Unlimited, 05-03-2007// (последнее посещение - 28.10.2013).

4. Jacobs, James B. \& Kimberly Potter. (1998). Hate Crimes: Criminal Law and Identity Politics. New York: Oxford University Press, pp. 130-144.

5. O'Grady, William (2011). Crime In Canadian Context: debates and controversies. Oxford University Press, p. 161.

\section{References}

1. Esakov G. A., Krylova N. E., Serebrennikova A. V. Ugolovnoe pravo zarubezhnykh stran: uchebnoe posobie. - M.: Prospekt, 2013. $334 \mathrm{~s}$.

2. Kochoi S. M. Rasizm: ugolovno-pravovoe protivodeistvie: monografiya. - M.: Prospekt. 2007.144 s.

3. Abrams, J. House Passes Extended Hate Crimes Bill, Guardian Unlimited, 05-03-2007// (poslednee poseshchenie - 28.10.2013).

4. Jacobs, James B. \& Kimberly Potter. (1998). Hate Crimes: Criminal Law and Identity Politics. New York: Oxford University Press, pp. 130-144.

5. O'Grady, William (2011). Crime In Canadian Context: debates and controversies. Oxford University Press, r. 161. 